\title{
A repozitóriumok üzemeltetésének jogi kérdései
}

Az adott egyetem vagy intézmény tudományos tevékenységét napjainkban a repozitóriumok reprezentálják leginkább, amelyeket általában a könyvtárak üzemeltetnek, ezért előadásomban szeretném összefoglalni e dokumentumés publikációs szerverek üzemeltetése kapcsán felmerülő jogi kérdéseket.

Fontosnak tartom már az elején leszögezni, hogy a nyílt hozzáférésü dokumentumok szerzői jogilag ugyanúgy védettek, mint a hagyományos publikációk.

A nyílt hozzáférés két ajánlott módja közül most a zöld útra szeretnék koncentrálni, ami a publikált tudományos szövegeknek az intézményi vagy tematikus dokumentumszerveren, repozitóriumban történő archiválását és nyilvánossághoz közvetítését jelenti nyílt hozzáféréssel.

Amikor egy szerző létrehozza új alkotását, a törvény erejénél fogva automatikusan létrejön a szerzői jogi védelem is. A szerzőt ettől a pillanattól kezdve megilleti a személyhez füződő jogok és vagyoni jogok összessége.

A szerzői vagyoni jog elsődleges célja, hogy a szerzőnek (ill. a jogosultaknak) müve bármely felhasználása után anyagi ellentételezést, díjazást írjon elő. Tapasztalataim szerint müfelhasználás alatt alapvetően mást értenek a könyvtárosok és a jogászok. Tulajdonképpen szerzői jogi szempontból „felhasználás” alatt a többszörözést és a mű mások számára történő érzékelhetővé tételét értjük.

Hatályos szerzői jogunk példázódó módon rögzíti azokat a konkrét felhasználási módokat ${ }^{1}$, amelyek esetén a szerzőt díjazás, ellenszolgáltatás illeti meg. Azonban a mü bármilyen más, mások számára történő érzékelhetővé tétele is engedélyköteles.

Esetünkben két műfelhasználási mód releváns, a digitális többszörözés és az ún. on-demand nyilvánossághoz közvetítés.

Az archiválás, a digitalizálás a szerzői jog fogalomrendszerében többszörözésnek minősül, hiszen ahhoz, hogy a müvet analógból digitális formátumúvá alakítsuk annak másolására van szükség.

${ }^{1}$ Szjt. 17. §. Forrás: http://net.jogtar.hu/jr/gen/hjegy_doc.cgi?docid=99900076.TV [2015. 08. 01.] 
A szerző kizárólagos joga, hogy művét többszörözze, és hogy erre másnak engedélyt adjon² ${ }^{2}$ Az Szjt. 18. § (2) bekezdése szerint a mü tárolása digitális formában elektronikus eszközökön többszörözésnek minősül, amely szintén a szerző kizárólagos jogai közé tartozik.

Továbbá az Szjt. 26. § (8) bekezdése a szerző kizárólagos jogai közé sorolja műve online felhasználásának engedélyezését is. „E joga kiterjed különösen arra az esetre, amikor a müvet vezeték útján vagy bármely más eszközzel vagy módon úgy teszik a nyilvánosság számára hozzáférhetővé, hogy a nyilvánosság tagjai a hozzáférés helyét és idejét egyénileg választhatják meg." "' (Ezt nevezzük lehívásos vagy ún. on-demand típusú hozzáférésnek.) Ez a felhasználási mód valósul meg, egyrészt amikor a müveket számítógépes hálózat útján, online tesszük hozzáférhetővé, másrészt pedig amikor a műveket eljuttatjuk a szolgáltatást igénybe vevő közönség egyes tagjaihoz.

Ezenkívül az Szjt. 27. §-a értelmében a szakirodalmi müvek és a nagyobb terjedelmü, nem színpadra szánt szépirodalmi mủvek (pl. regények) online felhasználását a jogalkotó a kizárólagos engedélyezési jog megszerzéséhez köti.

A nyilvános szolgáltatásokat nyújtó könyvtárak esetében ez azt jelenti, hogy a szakirodalmi mủvek, tudományos publikációk archiválása, digitalizálása az Szjt. 35. § (4) bekezdése alapján engedélykérés és díjfizetés nélkül lehetséges, amennyiben az jövedelemszerzés vagy jövedelemfokozás célját közvetve sem szolgálja, és az Szjt.-ben felsorolt valamelyik felhasználási célt szolgálja. Ugyanakkor a digitalizált szakirodalmi müvek online felhasználása, vagy on-demand nyilvánossághoz közvetítése csak a jogtulajdonosokkal kötött felhasználási szerződés birtokában lehetséges.

Jogtulajdonos az, akitől engedélyt kell kérni a mü felhasználására, illetve akinek díjat kell fizetni a mü felhasználásáért. Ez tulajdonképpen lehet maga a szerző vagy aki vagyoni jogait öröklés vagy átruházás, átszállás alapján megszerzi.

Amennyiben a szerző munkaviszony szerinti munkaköri kötelezettsége keretében készít el a müvét (ún. szolgálati mü) ${ }^{4}$, arra nézve a vagyoni jogok az Szjt. alapján a munkáltatóra szállnak át.

Fontosnak tartom megjegyezni, hogy a munkaviszonynak a mü keletkezésekor kell fennállnia, a jogkövetkezményeket nem érinti a munka-

\footnotetext{
${ }^{2}$ Szjt. 18. § (1) bek.

${ }^{3}$ Szjt. 26. § (8) bek.

${ }^{4}$ Szjt. 30. §
} 
viszonynak ezt követően történő megszünése. Szükséges továbbá, hogy a szerzőnek a mü létrehozása kifejezetten munkaköri kötelezettségét képezze, amelyre vonatkozólag a szerző munkaköri leírása, munkaszerződése az irányadó.

A müre vonatkozó vagyoni jogokat a mü átadásával a munkáltató az Szjt. alapján megszerzi. E jogszerzés azonban nem teljes körü, mert a munkáltató nem szerzi meg a szerző csak kötelező közös jogkezelés útján érvényesíthető méltányos díjigényeit (például üreskazetta, reprográfiai, nyilvános haszonkölcsönzési jogdíj stb).

Természetesen a munkáltató az általa megszerzett vagyoni jogokkal szabadon rendelkezhet. A müvet

- titokban tarthatja vagy felhasználhatja,

- másnak bármilyen terjedelmü felhasználást engedhet, vagy

- a vagyoni jogot magát is átruházhatja.

Ha a munkáltató harmadik személyeknek ad át a müre vonatkozó felhasználási jogokat, akkor az általános szabály szerint a szerzőt megfelelő díjazás illeti meg. A díjigény érvényesen (természetesen csak írásban és kifejezett nyilatkozattal) ki is zárható.

Gyakori, hogy a szerző egy kiadónak engedi át a számunkra releváns müfelhasználási jogait. A legtöbb kiadó engedélyezi a publikációk intézményi vagy tudományterületi repozitóriumokban történő párhuzamos elhelyezését. Ahhoz, hogy egy szerző biztosítsa magának a jogot cikkének online repozitóriumban vagy saját intézményének ingyenesen elérhető dokumentumszerverén történő párhuzamos elhelyezésére, a kiadóval kötött szerződést ennek értelmében kell megkötnie.

Az úgynevezett SHERPA/RoMEO lista részletesen tájékoztat arról, hogy a kiadók milyen kiadói politikát vallanak a párhuzamos elhelyezés kérdésében. E lista tartalma azonban jogilag nem döntő érvényü, inkább csak orientáló jellegű számunkra. Kétség esetén mindig a hatályos kiadói szerződés érvényes!

Lényeges, hogy minket, repozitórium üzemeltetőket a jogtulajdonos biztosítson arról, hogy jogosult az adott müfelhasználásra engedélyt adni, amennyiben szolgálati müről van szó, akkor az adott munkáltatótól, mint jogtulajdonostól, kell engedélyt szereznünk a műfelhasználásra. Amenynyiben a releváns műfelhasználási jogokat a szerző átadta egy kiadónak, úgy a kiadó nyilatkozatát kell beszereznünk arról, hogy az adott müvek 
szerzőivel kötött megállapodások alapján rendelkezik a müvek felhasználási jogaival és jelen nyilatkozat vagy szerződés aláírásával igazolja és szavatolja, hogy a szerződésben meghatározott felhasználási jogok átruházására jogosult.

Összefoglalva fontosnak tartom a kiadóval vagy a jogtulajdonossal kötött szerződésben rögzíteni, hogy a kiadó/jogtulajdonos szavatol azért, hogy a művön nem áll fenn harmadik személynek olyan kizárólagos szerzői vagyoni joga, amely a repozitórium üzemeltetőjének jogszerzését és müfelhasználását korlátozná vagy akadályozná. E tekintetben más harmadik személyt a repozitórium üzemeltetőjével szemben semmiféle jog nem illeti meg, és ebből eredően a repozitórium üzemeltetőjével szemben semmiféle jogcímen díjigény nem érvényesíthető.

Szintén nagyon sarkalatos része a megállapodásnak - véleményem szerint - egy esetleges jogsértés esetén felmerülő felelősség kérdése.

A repozitórium üzemeltetőjének egyfelöl biztosítania kell a müvek védelmét a szerzői jog védelmére szolgáló hatásos müszaki intézkedéssel. Az Szjt. meghatározza a hatásos müszaki intézkedés fogalmát: müszaki intézkedés minden olyan eszköz, alkatrész vagy technológiai eljárás, illetve módszer, amely arra szolgál, hogy a szerzői jog jogosultja által nem engedélyezett cselekményeket - rendeltetésszerü müködése révén - megelőzze, illetve megakadályozza. ${ }^{5}$ Másfelől tudjuk, hogy tulajdonképpen nem létezik olyan hatásos müszaki intézkedés, amelyet ne lehetne feltörni, megkerülni.

Ezért fontos lefektetni a szerződésben egyrészt a technikai paramétereket, vagy legalább azt, hogy a felek kijelentik, hogy teljes mértékben tisztában vannak a védelmi DRM-technológia tulajdonságaival, müködésével, az abban rejlő lehetőségekkel és annak korlátaival, valamint elismerik, hogy az alkalmazott DRM-technológia megfelel az Szjt. 95. § (3) bekezdésében meghatározott hatásos müszaki intézkedés fogalmának.

Másrészt szintén fontos lenne rögzíteni, hogy a repozitórium üzemeltetője nem felelős akkor, ha harmadik személy ezt a hatásos müszaki intézkedést megkerüli, és jogtalanul használja fel a védett müveket. A jogtulajdonos ebben az esetben közvetlenül e jogsértő harmadik személlyel szemben érvényesítheti igényét, és a repozitórium üzemeltetőjével szemben semmilyen követelést nem támaszthat.

\footnotetext{
${ }^{5}$ Szjt. 95. § (3) bek.
} 


\section{Rezümé}

Az adott egyetem vagy intézmény tudományos tevékenységét napjainkban a repozitóriumok reprezentálják leginkább, amelyeket általában a könyvtárak üzemeltetnek, ezért a tanulmányomban összefoglalom e dokumentum- és publikációs szerverek üzemeltetése kapcsán felmerülő jogi kérdéseket.

A nyílt hozzáférésủ dokumentumok szerzői jogilag ugyanúgy védettek, mint a hagyományos publikációk. A nyílt hozzáférés ajánlott módjai közül írásomban a zöld útra koncentrálok, ami a publikált tudományos szövegeknek az intézményi vagy tematikus dokumentumszerveren, repozitóriumban történő archiválását és nyilvánossághoz közvetítését jelenti nyílt hozzáféréssel. A nyilvános szolgáltatásokat nyújtó könyvtárak esetében a szakirodalmi múvek, tudományos publikációk archiválása, digitalizálása az Szjt. 35. § (4) bekezdése alapján engedélykérés és díjfizetés nélkül lehetséges, amennyiben az jövedelemszerzés vagy jövedelemfokozás célját közvetve sem szolgálja, és az Szjt.-ben felsorolt valamelyik felhasználási céllal összhangban van. Ugyanakkor a digitalizált szakirodalmi művek online felhasználása vagy on-demand nyilvánossághoz közvetítése csak a jogtulajdonosokkal kötött felhasználási szerződés birtokában lehetséges.

Gyakori, hogy a szerző egy kiadónak engedi át a számunkra releváns müfelhasználási jogait. A legtöbb kiadó engedélyezi a publikációk intézményi vagy tudományterületi repozitóriumokban történő párhuzamos elhelyezését. Ahhoz, hogy egy szerző biztosítsa magának a jogot cikkének online repozitóriumban vagy saját intézményének ingyenesen elérhető dokumentumszerverén történő párhuzamos elhelyezésére, a kiadóval kötött szerződést ennek értelmében kell megkötnie.

A kiadóval vagy a jogtulajdonossal kötött szerződésben célszerü rögzíteni, hogy a kiadó/jogtulajdonos szavatol azért, hogy a müvön nem áll fenn harmadik személynek olyan kizárólagos szerzői vagyoni joga, amely a repozitórium üzemeltetőjének jogszerzését és mủfelhasználását korlátozná vagy akadályozná. Sarkalatos része a megállapodásnak - véleményem szerint - egy esetleges jogsértés esetén felmerülő felelősség kérdése. Fontos lenne lefektetni a szerződésben, hogy a repozitórium üzemeltetője nem felelös akkor, ha harmadik személy a hatásos müszaki intézkedést megkerüli, és jogtalanul használja fel a védett mủveket.

\section{Legal aspects of the operation of repositories}

Nowadays the scientific activity of a university or an academic institution is represented principally by the repositories operated by libraries. Therefore I will sum up the issues of law regarding the operations of the document and publication servers. 
It is important to point out at the very beginning, that the open access documents are copyrighted the same way as traditional publications are. I would like to focus on the "green (licensed) road", which is one of the recommended types of open access. This would mean the archiving and making accessible the published scientific texts on institutional or thematic document servers (repositories). Pursuant to paragraph 35 (4) of the Hungarian Copyright Act public libraries may archive and digitize scientific publications without requesting permisssion or paying fees, provided that they have no intention to profit or increase profits even in an indirect way, and the digitisation serves one of the purposes enlisted in the Copyright Act. However, the use of these digitized scientific publications either online or via on-demand supply service requires the written consent of the rightsholder in the form of copyright license agreement.

The author confers often his rights relevant for us to the publisher. Most of the publishers allow publications to be positioned also in an institutional or disciplinary repository. In order to have the right to make his publication accessible in an open access online repository or in the document server of his institution the author needs to include this in the contract with his publisher. It should also be emphasized in the contract that the publisher and/or rightholder warrant that the article is not the work of a third party and/or they have an exclusive right (copyright).

The liability issues and the liquidated damages are also pivotal parts of the agreement in the case of a breach of the contract. Thus, for example, it should be laid down in the contract, that the repository operator is not liable if third parties illegally bypass the technological measures and use the protected works.

AMBERG ESZTER

fökönyvtáros, jogász OSZK Könyvtári Intézet 